\title{
Character education and the rise of mental health in Muhammadiyah Boarding School
}

\author{
Rahmah Hidayati ${ }^{1}$, Arif Rahman ${ }^{1}$, Zalik Nuryana ${ }^{2}$ Yusutria $^{1}$ \\ ${ }^{1}$ Department of Islamic Education, Faculty of Islamic Studies, Universitas Ahmad Dahlan, Yogyakarta, Indonesia \\ ${ }^{2}$ School of Education Science, Nanjing Normal University, Nanjing, China
}

\begin{tabular}{l} 
Article Info \\
\hline Article history: \\
Received Feb 15, 2021 \\
Revised Nov 6, 2021 \\
Accepted Nov 20, 2021 \\
\hline
\end{tabular}

Keywords:

Boarding school

Independence

Religious character

Social character

Ta'zim

Team building

\section{Corresponding Author:}

Zalik Nuryana

Department of Islamic Education, Universitas Ahmad Dahlan Yogyakarta

Jl. Ringroad Selatan, Tamanan, Banguntapan, Bantul, Daerah Istimewa Yogyakarta 55191, Indonesia

Email: zalik.nuryana@pai.uad.ac.id

\begin{abstract}
This study aimed to determine various characters implemented at modern Islamic Muhammadiyah Boarding School (MBS). This school is in Pleret, Bantul, Special Region of Yogyakarta, Indonesia. This research was a case study. The researcher carefully investigated a program, event, activity, process, or individual whose case is time-limited, and activity is determined by using a qualitative approach. The data were analyzed using descriptive analysis. The researcher has analyzed the research based on data obtained from interviews, observation, and documentation. The characters implemented at MBS are religious character, independence, social character, team building, and ta'zim (RISTA). Implementing these character values benefits students' mental health, resulting in strong Islamic personalities and good mental health MBS graduates.
\end{abstract}

This is an open access article under the CC BY-SA license.

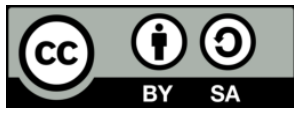

\section{INTRODUCTION}

Character education is not only the memorizing process of learning materials in the classroom but character-building needs habituation. Continuous habituation can make the students be skilled. For example, habituations of doing good and honest action, being sportive and shy to act lazy and let the environment dirty. Character is not built instantly but should be trained continuously, seriously and proportionally to reach ideal shape and strength, in achieving a intelligent generation capable of character and personality [1]-[3]. Character strengths are described as traits that are inherently positively valued and contribute to a good life [4]. Since humans' creation, they have various life potentials and functions in this world. Therefore, humans have selection position, the best and primary humans, in the formation of attitudes in addition to educating reason [5], [6]. Being the best and central, humans should have a strong character.

Zubaedi presented his opinion on character education, which is more than a good nature that has a core in the teaching program and develop character or behaviors by inspiring societies' values and belief as moral strength. In the life through honesty, trustworthiness, discipline, and cooperation which emphasizes on affective aspect (feeling/attitude) without leaving cognitive aspects (rational thinking), skill aspects (skill to process data and present opinion [7]. Substantially, character education aims to guide and facilitate children to have positive characters [8]. A learning environment is improved through daily implementation, direct instruction, literature use, and parents' involvement [9], model example and sanction provision [10].

The objective of character education is to improve human resource quality because it will determine nation development. The qualified character should be formed and maintained from an early age because it is a golden period to identify an individual's character. Developing children's character is our parents and our 
responsibilities. Although our parents are the main character education, empirical research indicates that they want all mature people to have contact with their children and contribute to such education, especially their children's teachers. The characters become the priority which is taught by school, including in England [11]. As a place for character education, the school environment must have a strategy in directing and guiding children's character into positive direction [12].

Character education is embedded through values education that becomes a nation character fundamental value. Therefore, it is values development which comes from Indonesia nation ideology, religion, culture, and values formulated in national education, to become a mature human being and have the abilities in accordance with the expected goals. Character values which are developed at school are in relationship with the Allah, self [13], environment, and nationality. Education institution influences in creating graduates, including in applying character education. For example, in the Study Program of Islam Religion Education of Ahmad Dahlan University, the character education is packaged in ORNAMI (Orientasi Penanaman Nilai ai-Islam dan Kemuhammadiyahan) activity which is aimed to provide understanding on students' religious values [14].

Character education in essence is to carve morals through the process of knowing the good, loving the good, and acting the good, namely an educational process that involves cognitive, emotional, and physical aspects, so that noble character can be engraved into a habit of the mind, heart, and hands [15]. We can distinguish three types of "character education": i) simple moral education (basically, Kohlberg's moral education in the classroom), ii) just, community education (Deweyesque' practice which emphasizes on democratic decision making outside the school), and iii) simple character education (try to build character in or outside the first grade attitude at one moment by emphasizing good behaviors) [16]. Boarding school is an Islamic educational institution that has education, and social function by using dormitory system guided by teachers and kyai to become expert in Islam (mutafaqqih fiddiin) and warner in goodness (mandzirul qawm), [17]. Pesantren is considered to give birth to a young generation who is not only smart in knowledge, but rather have a good personality or character, because pesantren is also the most important and oldest educational institution in Indonesia engaged in the development of Islamic religious knowledge [18].

Current boarding schools can be classified into traditional boarding schools (TBS) and modern boarding schools (MBS). In its teaching, TBS only teach and deepen classical Islam as the education core. In the TBS, it teaches classical Islam without introducing a general lesson. While MBS has embedded general lessons in the Islamic school, which is developed public school types in boarding school environment. Boarding school education is aimed to enrich scientific treasure of each students (santri), improve morale, train or improve spirit, respect humanistic spiritual values, teach moral attitudes and behaviors [19], and prepare Islamic religious santri to live in modest life with a clean heart [20]. In the $21^{\text {st }}$ century [21], students' character and emotional-social competence will bring to leading school [22], character education requires strategies to be applied at school [23].

Susan divided three types of Islam education: Education of Muslims, Education for Muslims, and Education about Islam [24]. Boarding school is a solution to embed students' character education because all students' activities are integrated into a comprehensive curriculum system which covers three typologies of Islam education. Besides, boarding school is also an Indonesian special education institution which can respond to the challenges of the modernization era. From this explanation, this research has two research questions: 1) what are the values of character education at the Muhammadiyah Boarding School Pleret? and 2) how is the implementation of character education values in Muhammadiyah Boarding School Pleret Bantul?

\section{METHOD}

The research was a case study field that utilized a qualitative approach. In this research, the researchers carefully observed a program, event, activity, process, or a group of individuals whose cases are limited by the determined time. The research flow can be seen in Figure 1. The informants were selected to understand the history of Modern Islamic Muhammadiyah Boarding School (MBS) Pleret Bantul, Yogyakarta, Indonesia, and their teaching-learning activities. The selected informants were the director, manager, dormitory assistant, and some santris. Observation, interviews, and documentation are administrated to obtain information about the implementation of character education to gain relevant, indepth, and appropriate information to support this research. The triangulation technique was utilized as data analysis. It was done by combining all data which is obtained from a determined data source, and the conclusion was drawn. Observations were made to gather information about MBS's character education program.

The information gathered serves as the foundation for determining the issue under consideration. Interviews with the MBS Director, teachers, and students were conducted. In this study, interviews were conducted to obtain comprehensive information about the implementation of character education in MBS, 
beginning with policy, planning, implementation, evaluation, and problems encountered during implementation. Documentation is used at MBS to obtain information about policy letters, schedules, and character education programs. Step 1: The researcher conducts preliminary research and then records the findings used as the foundation for this research. Step 2: The researcher creates an interview proposal and an interview instrument. Furthermore, researchers conducted interviews and observations to collect data on how students' mental health is developed because of the character of life they live at Muhammadiyah Boarding School Pleret. Step 3: After collecting the data, it is interpreted and concluded using descriptive analysis. The study's findings were presented in the form of tables and figures.

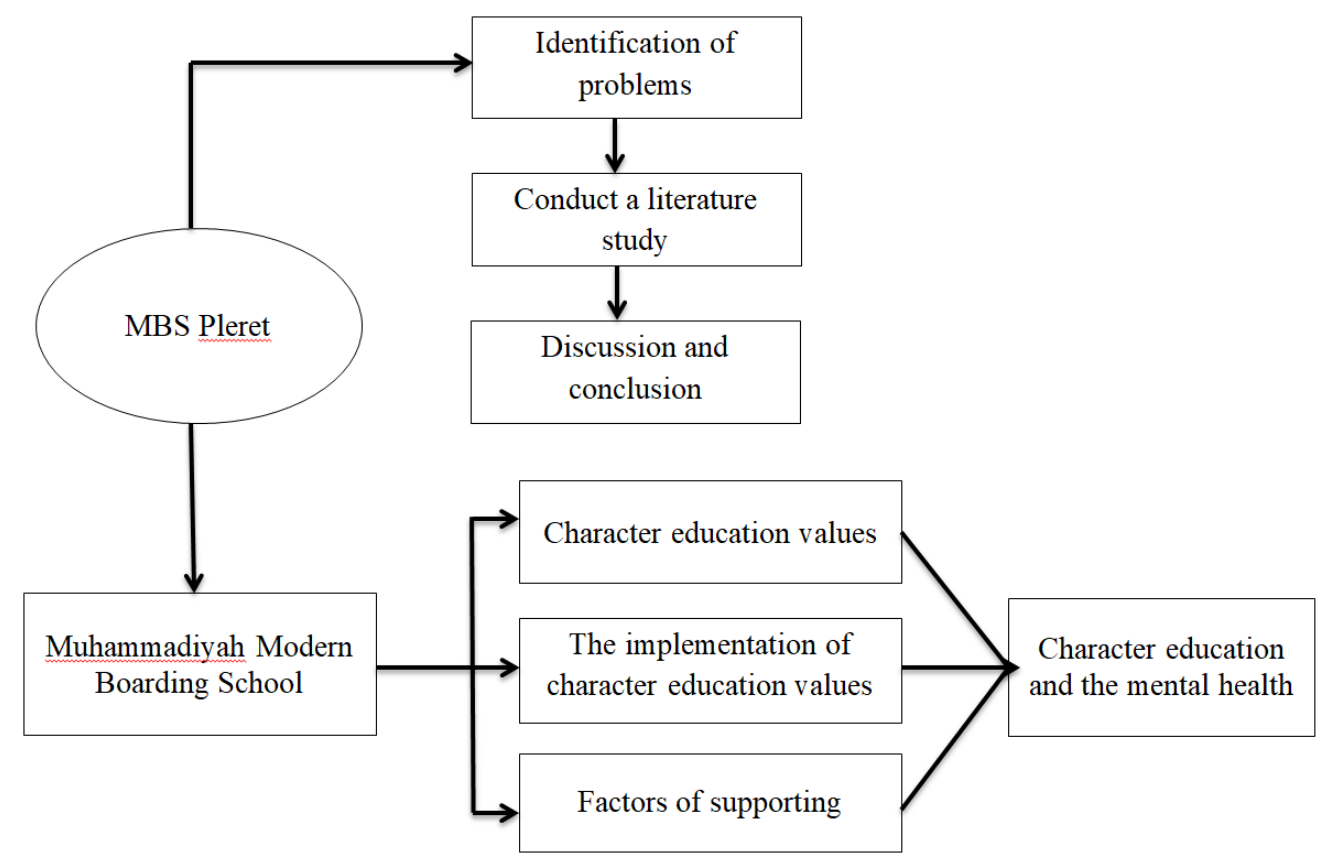

Figure 1. Research flow

\section{RESULTS AND DISCUSSION}

There are four principle indicators of character education implementation at school in California to support high academic achievement; i) a good school ensures physical cleanliness and environment is maintained well. ii) a good school will uphold justice, equality, care, and respect. iii) a good school has students who contribute in meaningful ways. iv) a good school promotes their studying community well and care of social relation [25]. Character is a set of complex psychological characteristics which enable an individual act as a moral agent. Character education is good and the most primary education to control behaviors [26]. Mental health heavily depends on emotional states such as sentiments, reactions or stress, motivation, and spirit [27]. Research on mental health has always been a topic of research that continues to grow with various approaches and methods [28]. It is also an effort to guide an individual's behaviors through determined standards and provide a way to respect individuals' perspectives and values at school [29], [30]. In the context of MBS, character education is at the heart of the implementation of school activities. Every activity from waking up until going back to sleep has an instilled character value. In addition, the MBS program can make this school develop well, one of which is indicated by the increasing interest of new students in this school.

Lickona explained 11 basic principles of character education: First, character educator promotes core ethics values as good character base. Second, "Character" should be defined comprehensively to accompany thinking, feeling, and behavior. Third, effective character education needs an intentional, proactive, and comprehensive approach that encourages core value in all school life phases. Four, school should be care community [31]. Fifth, to develop character, students need an opportunity for moral action. sixth, effective character education covers a meaningful and challenging academic curriculum that respects all students and help their success. seventh, character education should try to develop students' intrinsic motivation. Eighth, School staff should be study and moral community in which all share responsibilities for character education and try to obey same core values that guide students' education. Ninth, character 
education needs moral leadership from staf and students. Tenth, school should recruit parents and societies' members as full partner in Building character. Eleventh, character education evaluation should assess school character, school staff function as character educators and how far the students manifest good character [32]. It is found a positive effect on school ability to fulfill students' social, emotional and cognitive needs after social development program for all school citizens which is based on empirical proof from education psychological point of view [33]. The psychological approach is seen as a new approach which can help cognitive development for moral and character education from preschool to university [34].

Schools have used the principles of character education in the context of MBS. Schools collaborate and coordinate with all parties to streamline the implementation of character education; this is, of course, also a promotion of schools to be widely known in the community. MBS's collaboration with the community is going well, allowing this school to be accepted in the community and provide benefits. Character education is implemented at MBS by school and dormitory staff to provide 24-hour monitoring of student activities. Concept of character education implementation in MBS Pleret can be seen in Figure 2.

\subsection{Character education values at Muhammadiyah Boarding School Pleret}

The result of research performed at Modern Islamic Muhammadiyah Boarding School (MBS) Pleret Bantul is related to character education implementation, which is explained as follows: Character values applied at MBS Pleret can be categorized into four aspects so-called "RISTA" term. It stands for religious character, independence; social character, team building, and ta'zim as shown in Table 1. The five points are a part of values accumulation found in boarding school life, summarized by the researchers in the five aspects.

Based on Table 1, the five aspects are connected because it is impossible if each point run by itself and does not support each other. It's unlikely that they have religious character but do not have social character. Also, the social character must be built from religious values, cooperation, and respect towards teachers. The five aspects conceptualized by the researchers become an offer in the boarding school. Figure 2 is the visualization of the five aspects, which are packaged to be an exciting concept.

Table 1. Religious character, independence, social character, team building, and ta'zim

\begin{tabular}{|c|c|}
\hline Character & \\
\hline Religious character & $\begin{array}{l}\text { Religious character is the primary character which must exist in MBS Pleret Bantul. The religious values which } \\
\text { can be found are five daily prayers, sunah salat (tahajjud and duha), Monday-Thursday Fasting, Tadarus Al- } \\
\text { qur'an, tahfidz, etc. The emphasizing of character values concerning religious matters becomes the Islamic } \\
\text { religious students' (santri)' basic capital at Modern Muhamadiyah Boarding School (MBS) Pleret Bantul. } \\
\text { Islamic Boarding School is a religious institution which protrudes their religious values. Certainly, the Islamic } \\
\text { religious students (santri) must be taught with more religious values than students who live outside the boarding } \\
\text { school. }\end{array}$ \\
\hline Independence & $\begin{array}{l}\text { Independence is also trained in MBS Pleret environment to build Islamic religious students' (santri) character. } \\
\text { Independence is required by all individuals because and individual does not feel the dependence towards other } \\
\text { people. Moreover, Islamic religious students (santri) who study at the boarding school are demanded to have } \\
\text { independence. It is different from the students who do not stay at the dormitory because they are still taken care } \\
\text { of by their parents. In other words, Islamic religious students (santri) at the boarding school are required to be } \\
\text { independent so that they can do everything independently although they help each other. They don't only teach } \\
\text { Islamic religious students (santri) to wash clothes, take care of themselves, or manage time, but also teach them } \\
\text { to be brave (active). Khitobah Ashgar and Khitobah Akbar is also found in the program of Modern Islamic } \\
\text { Muhammadiyah Boarding School Pleret. The objective is Islamic religious students (santri) will be able to } \\
\text { become master of ceremony if they're asked because they have been trained to do it. }\end{array}$ \\
\hline Social character & $\begin{array}{l}\text { Social character is a character which is embedded through interaction with peers and teachers, the care act } \\
\text { towards the environment, etc. In boarding school, they must use Arabic and English. To dig their Arabic and } \\
\text { English skill, they are expected to interact/speak with their friends teachers in the boarding school more often. } \\
\text { Social values are seen from communication using foreign languages and social character values are built through } \\
\text { their attention to peers. The objective of social character is to have sensitivity towards themselves, environment } \\
\text { or other people who need our assistance. }\end{array}$ \\
\hline Team building & $\begin{array}{l}\text { Team building is more often called as cooperation. When they live at boarding school, Islamic religious students } \\
\text { (santri) do not live alone and for a period of time, their solidarity is needed. The cooperation is also built-in their } \\
\text { lives such as doing assignment together, community service to clean and maintain the boarding school } \\
\text { environment, sport, etc. } \\
\text { Building Islamic religious students (santri)'s cooperation has a fundamental objective which is to strengthen and } \\
\text { tighten their relationship. They live separately from parents. So they are trained to be independent and able to } \\
\text { cooperate well. In the future, they will be more intimate, solid and able to cooperate with other people. }\end{array}$ \\
\hline Ta'zim & $\begin{array}{l}\text { Ta'zim is a form of Islamic religious students' (santri) respect to teachers or ustadz/ustadzah. In the Islamic } \\
\text { boarding school, ta'zim to teachers is ordinary and sacred because it is a form of respect towards teachers. } \\
\text { It is challenging to find Islamic religious students (santri) who speak rude with ustadz/ustadzah in the boarding } \\
\text { school. However, it is easy to find rude students outside the boarding who do not respect teacher. In Islamic } \\
\text { Muhammadiyah Boarding School, the students (santri) are taught to respect, obey, be polite and well-mannered } \\
\text { towards older people. As the term which mentions "Respect older people, love young people", it is clear that } \\
\text { they are taught to respect both peers and older people. }\end{array}$ \\
\hline
\end{tabular}




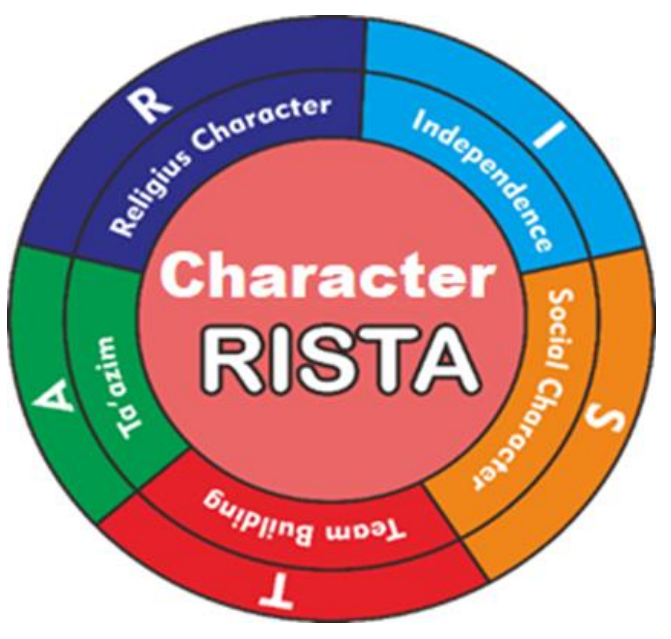

Figure 2. Conception (RISTA) of character education aspects at Islamic MBS Pleret

RISTA characters are summarized in the five values aspects in activities or programs arranged in programmed and incidental daily, weekly, monthly and annual activities aimed at building the Islamic students' (santri) character and personality to be better [35]. The researchers figure out personality characters values in the following tabulation. Character aspects drawn in RISTA contain values drawn in the santri's life at the boarding school. Moral emotion has a function to be an important connector between moral personality development and proximal decision making which is seen from daily moral behavior [36]. Daniel believes that character education needs a clear psychological understanding of disposition and development coherence and approach, which can be maintained for the appropriate education and what is known about effective teaching and learning [34]. The importance of character education program in the school curriculum, work definition of character education and teachers and parents' character in the character education program. The objective is to prepare future leader [37]. Table 2 explains values that are found in character developed at school. Considering the five RISTA aspects conceptualized by the researchers, the picture on character education runs as religious, independence, social, cooperation, and respect values. Certainly, there is character values found there, but the researchers limit them in some values. The researchers realize that there will be many relevant values contained in each aspect.

\subsection{The implementation of character education values at Islamic Muhammadiyah Boarding School}

The implementation process of character education values at MBS Pleret utilizes some methods to make the delivery process more effective and efficient and reach the desired result. The methods utilized are: i) Habituation method is one of reasonable educating efforts in building humans' character. Educators use it to accustom students repeatedly until it becomes a habit that cannot be easily left and will be brought until their old days; ii) An exemplary method is a proper and appropriate action to be imitated. Ustadz/ustadzah are their primary role model at Islamic Boarding School because their Islamic students (santri) will see how their teachers act, speak, and politely and well-mannered behave; iii) Advising method is one of the activities which builds students' moral. Therefore, Islamic students (santri) will have a sense of being noticed and loved by their teachers. Advise giving aims to improve and disenchant them so that they do not violate the rules that prevailed in the boarding school; iv) Reward and punishment method. The reward is given to Islamic students (santri) who have the potential to motivate another sentry to do as he does. While punishment is given to who violate the rules and regulation in the boarding school. It is aimed to provide them deterrent effect so they will not repeat the same mistake.

Table 2. Character values content at Modern Islamic Muhammadiyah Boarding School (MBS) Pleret

\begin{tabular}{cll}
\hline No & \multicolumn{1}{c}{ Aspect } & \multicolumn{1}{c}{ Values content } \\
\hline 1 & Religious character & Thankfulness/ gratitude; sincerity \\
2 & Independence & Strong; brave; independent \\
3 & Social character & Care; empathy; inclusive; tolerance; attention \\
4 & Team building & Hard work; cooperation; solid \\
5 & Ta'zim & Respect; obedient; polite; tabarruk \\
\hline
\end{tabular}

Int J Public Health Sci, Vol. 11, No. 1, March 2022: 170-178 


\subsection{Factors of supporting and obstacle of character education values embedding process at Islamic Muhammadiyah Boarding School Pleret Bantul}

Four important aspects of character education are: i) Students need performance characters (work ethics, self-discipline, perseverance, initiative, teamwork) to perform their best academic work; ii) Students develop their performance character (ability to work harder, overcome obstacles, find excitement in their work which is completed well) from their school works; iii) Students need moral character (respect, justice, goodness, honesty) to create classroom relationship which makes learning environment positive; iv) Students develop moral character from their school work (for example by assisting their colleagues in performing their best work through "critical culture" which offers constructive feedback by learning ethic problem in the curriculum and using curricular learning in service project) that assist solving the real-world problem) [38]. Character education program designed in sociocultural understanding on development positively affects teachers' conversation, students' assignment, and anti-social behavior. Qualitative and quantitative data prove students' behavior development and teachers' capacity building to focus their time on delivery content during the course [33].

After the explanation of character education values as found in Islamic MBS Pleret and its implementation, the last problem formulations on the supporting factors in the embedding process which is done at modern Islamic Muhammadiyah Boarding School (MBS) Pleret Bantul are: i) Parents' support. Support, spirit, motivation, and prayer given by their parents are helpful for the character education process continuation at the Boarding School; ii) The consistency of ustadz/ustadzah assistance. It is performed 24 hours by them. They stay in the boarding school environment with all Islamic students (santri) or who are socalled as Musyrifah/dormitory head. Musyrifah is assigned to support, assist, keep, and monitor all santri's activities in the boarding school environment; iii) The boarding school program is dynamic and continuous. A dynamic and sustainable program will have a good impact on students, for example forming the professionalism of both students and teachers [39], in the Islamic perspective, this is called istiqamah. The programs arranged in the curriculum document of modern Islamic Muhammadiyah Boarding School (MBS) Pleret Bantul cover daily, weekly, monthly, and annual program; iv) Conducive boarding school atmosphere and environment. The environment can also be the supporting factor of character values embedding the process in the boarding school because good environment helps the process to run smoothly. The religious atmosphere that is carried out is the habit of reading the Qur'an [40]. The activity of reading the Qur'an that was carried out turned out to have an influence on mental health.

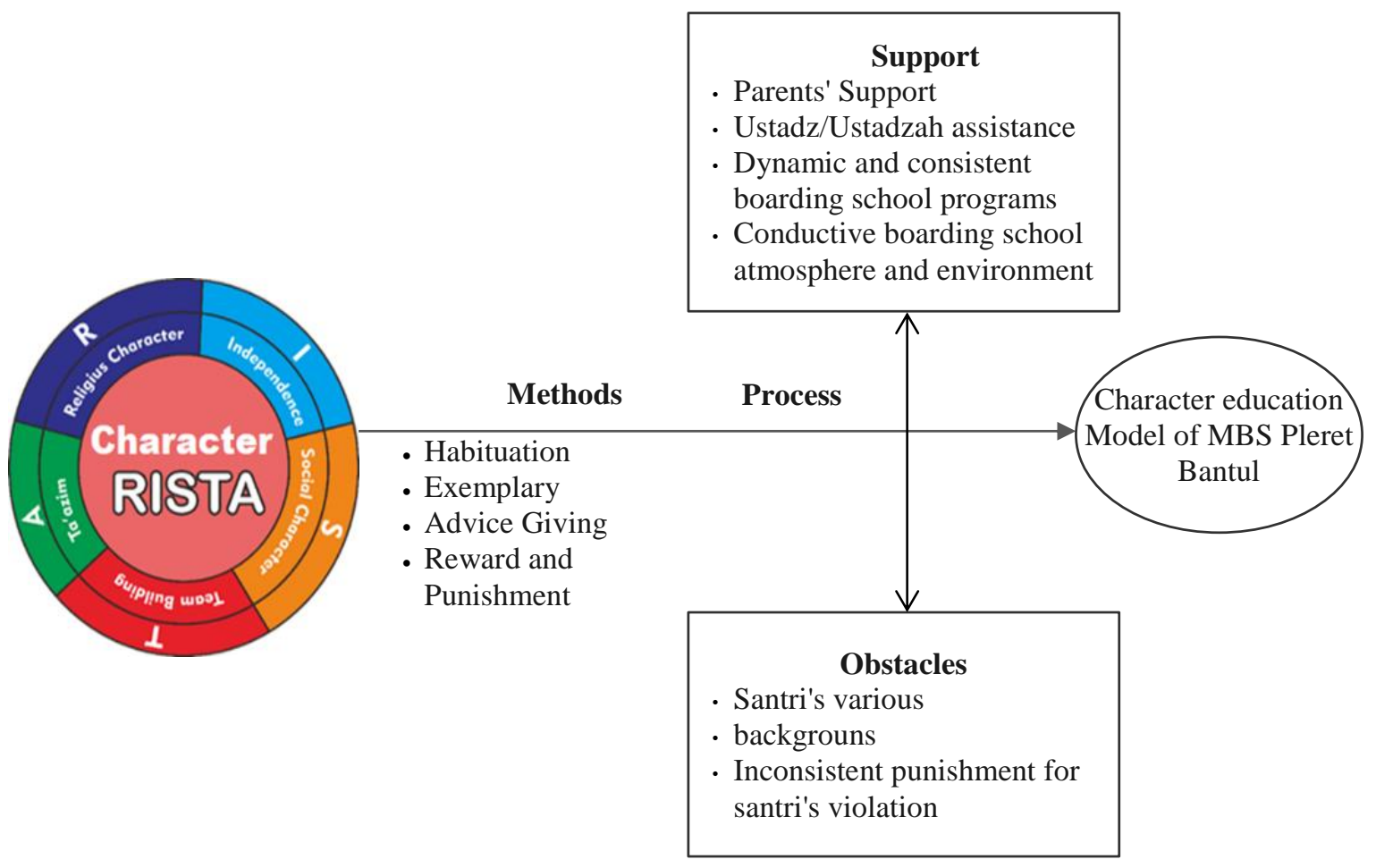

Figure 3. Concept of character education implementation in MBS Pleret 
Besides supporting factors that can be shown in Figure 3, there are also obstacles of character values embedding process at Modern Islamic Boarding School (MBS) Pleret, such as: i) The Islamic students' various backgrounds [41]. Although it is an extraordinary potential, it will be an obstacle at the boarding school because their local origin characters are still prevalent and language that cannot be understood and accepted easily by other friends; ii) Inconsistent punishment for Islamic students (santri). Violations performed by students are found in both educational institution and social boarding. The violations which they perform are late coming for Salat in a congregation or they do not perform daily duties. The violation will continuously occur if punishment is not given firmly. During the research, the researchers find some students do not maintain cleanliness, such as throwing rubbish carelessly, leaving the environment dirty and laundry falls. The teachers' role in guiding character education is also essential. It is done by the teachers in each condition, for example when they teach, give command or communicate with parents [42].

The research explained that primary school teachers perceive that they understand most of character education aspects and get bachelor's degree from private university affiliated with religion so that they have higher understanding of character education [43]. This research has drawn how the data and analysis are relevant with character education at modern Islamic Muhammadiyah Boarding School (MBS) Pleret Bantul seen from conception, implementation, and supporting and obstacle factors that can be drawn as the following. Character implementation has the potential itself. The design found here is RISTA. Then the researcher accumulates it with various types of analysis and data which is relevant with character education at modern Islamic Muhammadiyah Boarding School (MBS).

There are some methods of embedding character in the students. Film can be used to involve students in moral-dilemma moral to promote critical thinking and character development. The researchers perceive that film use in the classroom can challenge students to broaden and analyze their values and beliefs by checking popular film's moral dilemma [44]. However, boarding school has all needed in the character building. Students will be controlled since wake up to bedtime.

\section{CONCLUSION}

Based on explanation, the research concludes: First, character values in MBS Pleret contain four aspects named religious character, independence, social character, team building, and ta'zim (RISTA). It stands MBS's character values, which are instilled in students; aim to strengthen the personality of students and graduates by instilling them with strong characters and good mental health. Students are prepared to graduate with a strong Islamic character and good mental health. Second, character education implementation in MBS Pleret uses methods such as habituation, exemplary, advice, reward, and punishment. Third, supporting and obstacle factors of character education in MBS Pleret are parents' support, assistance consistency ustadz/ustadzah (teacher), dynamic and continuous boarding school program, conducive atmosphere, and environment. Otherwise, the obstacle factors are the Islamic students (santri)'s various backgrounds and inconsistent punishment to santri's violations.

\section{REFERENCES}

[1] H. Baharun, "Total Moral quality: a new approach for character education in Pesantren," Ulumuna, vol. 21, no. 1, pp. 57-80, 2017.

[2] E. V. Intania and S. Sutama, "The role of character education in learning during the COVID-19 pandemic," J. Penelit. Ilmu Pendidik., vol. 13, no. 2, pp. 129-136, 2020, doi: 10.21831/jpipfip.v13i2.32979.

[3] R. T. Wulandari and A. Tinus, "The reinforcement of the school culture-based character education," Ital. J. Sociol. Educ., vol. 13, no. 2, pp. 195-218, 2021, doi: 10.14658/pupj-ijse-2021-2-9.

[4] L. Wagner, "Good character is what we look for in a friend: character strengths are positively related to peer acceptance and friendship quality in early adolescents," J. Early Adolesc., vol. 39, no. 6, pp. 864-903, 2019, doi: 10.1177/0272431618791286.

[5] A. Abdullah, S. Masruri, and K. Bashori, "Islamic education and human construction in The Quran," Int. J. Educ. Learn., vol. 1, no. 1, pp. 27-32, Jun. 2019, doi: 10.31763/ijele.v1i1.21.

[6] M. Taufik, "Strategic role of Islamic Religious education in strengthening character education in the era of industrial revolution 4.0," J. Ilm. Islam Futur., vol. 20, no. 1, pp. 86-104, 2020, doi: 10.22373/jiif.v20i1.5797.

[7] Zubaedi, Character Education Design: Concepts and Applications in Educational Institutions (In Indonesia: Desain Pendidikan Karakter: Konsep dan Aplikasi dalam Lembaga Pendidikan). Jakarta: Kencana, 2011.

[8] OK.M. Daniel Syahindra, Siti Khadijah, Dahliah, Siti Aisyah, "Instilling the character of independence at the time of learning in early childhood at Kindergarten Aisyiyah Bustanul Athafal 02 Belawan (In Indonesia: Menanamkan karakter kemandirian pada saat belajar pada anak usia dini di Taman Kanak-kanak Aisyiyah Bustanul Athafal 02 Belawan)," Edu Riligia, vol. 4, no. 2, pp. 170-182, 2020, doi: 10.47006/er.v4i2.8247.

[9] N. Burke, S. Crum, M. Genzler, D. Shaub, and J. Sheets, "Building character education in our schools to enhance the learning environment," 2001, [Online]. Available: http://search.ebscohost.com/login.aspx?direct=true\&db=eric\&AN=ED453144\&site=ehost-live.

[10] Djailani AR, "Strategy character building of students at excellent schools in the city of Banda Aceh," IOSR J. Res. Method Educ. vol. 1, no. 5, pp. 49-59, 2013, doi: 10.9790/7388-0154959.

[11] J. Centre, "A Framework for character education in schools." The Jubilee Centre for Character \& Values. 2012, https://www.jubileecentre.ac.uk/527/character-education/framework (accessed Jan 14 2021). 
[12] E. R. Dewia and A. A. Alam, "Transformation model for character education of students," Cypriot J. Educ. Sci., vol. 15, no. 5, pp. 1228-1237, 2020, doi: 10.18844/cjes.v15i5.5155.

[13] L. A. Mitchell, "Integrity and virtue: The forming of good character," Linacre Q., vol. 82, no. 2, pp. 149-169, 2015, doi: 10.1179/2050854915Y.0000000001.

[14] Z. Nuryana, A. Rahman, and F. Setiawan, "The curriculum model of study program-based Muhammadiyah form of cadre," in Proceedings of the First International Conference on Progressive Civil Society (ICONPROCS 2019), 2019, vol. 317, no. IConProCS, pp. 208-211, doi: 10.2991/iconprocs-19.2019.44.

[15] B. Hasmayni, F. H. Siregar, and A. Aziz, "Establishment of character through boarding school education in students in Pondok Pesantren," in 4th Annual International Seminar on Transformative Education and Educational Leadership (AISTEEL 2019), 2019, pp. 318-321.

[16] M. Davis, "What's wrong with character education?," Am. J. Educ., vol. 110, no. 1, pp. 32-57, Nov. 2003, doi: 10.1086/377672.

[17] Y. Hanafi et al., "The new identity of Indonesian Islamic boarding schools in the 'new normal': the education leadership response to COVID-19," Heliyon, vol. 7, no. 3, 2021, doi: 10.1016/j.heliyon.2021.e06549.

[18] L. Dewi, F. Tentama, and A. M. Diponegoro, "Subjective well-being: mental health study among student in the islamic boarding school," International Journal Public Health Science (IJPHS), vol. 10, no. 1, pp. 146-158, 2021, doi: 10.11591/ijphs.v10i1.20610.

[19] A. A. R. Miftahul Khaer, Ahmad Yasser Mansyur, Ahmad Ridfah, "The effectiveness of writing the letter of gratitude technique in reducing the stress level of islamic boarding school student," Psikis J. Psikol. Islam., vol. 7, no. 1, pp. 79-85, 2021.

[20] F. Simpson, M. Haughton, and W. Van Gordon, "An identity process theory account of the impact of boarding school on sense of self and mental health: an interpretative phenomenological analysis," Int. J. Ment. Health Addict., 2021, doi: 10.1007/s11469-021-00503-4.

[21] J. Goodwin et al., "The use of film-based interventions in adolescent mental health education: A systematic review," J. Psychiatr. Res., vol. 137, no. February, pp. 158-172, 2021, doi: 10.1016/j.jpsychires.2021.02.055.

[22] A. S. Bencivenga and M. J. Elias, "Leading schools of excellence in academics, character, and social-emotional development," NASSP Bull., vol. 87, no. 637, pp. 60-72, Dec. 2003, doi: 10.1177/019263650308763706.

[23] J. H. Harris, "Character education in Pontiac Schools," Relig. Educ., vol. 25, no. 3, pp. 228-229, Mar. 1930, doi: $10.1080 / 0034408300250308$.

[24] S. L. D. M. A. Shaikh, "Defining Islamic education: differentiation and applications," Curr. Issues Comp. Educ., vol. 7, no. 1, pp. $5-18,2004$

[25] J. S. Benninga, M. W. Berkowitz, P. Kuehn, and K. Smith, "Character and academics: what good schools do," Phi Delta Kappan, vol. 87, no. 6, pp. 448-452, Feb. 2006, doi: 10.1177/003172170608700610.

[26] M. W. Berkowitz and M. C. Bier, "Research-based character education," Ann. Am. Acad. Pol. Soc. Sci., vol. 591, no. 1, pp. 7285, Jan. 2004, doi: 10.1177/0002716203260082.

[27] M. Khanmohammadi, "Assessing roles of environmental quality on the s tudents' mental health (Case Study: Students of Arak Sama High School, Islamic Azad University)," Int. J. Archit. Urban Dev., vol. 11, no. 2, pp. 63-70, 2021.

[28] Z. Nuryana, G. Al Murshidi, and A. Rahman, "Publication trends related to schizophrenia, mental health, and depression during COVID-19," Asian J. Psychiatr., p. 102878, 2021, doi: 10.1016/j.ajp.2021.102878.

[29] P. J. Harned, "Leading the effort to teach character in schools," NASSP Bull., vol. 83, no. 609, pp. 25-32, Oct. 1999, doi: $10.1177 / 019263659908360904$

[30] I. Mulyawati, "Improving health behavior standard through modern islamic boarding school," J. Kesehat. Masy., vol. 16, no. 3, pp. 445-451, 2021.

[31] Y. H. Suparta Rasyid, Dadang Suhardan, "Islamic boarding school supervision to creating smart students," in Proceedings of the 4th International Conference on Research of Educational Administration and Management (ICREAM 2020), 2021, pp. 1-5.

[32] T. Lickona, "Eleven principles of effective character education," J. Moral Educ., vol. 25, no. 1, pp. 93-100, Mar. 1996, doi: 10.1080/0305724960250110.

[33] R. White and Michael, "Building schools of character: the development, implementation, and evaluation of a school-based character education programme designed to promote cooperative learning and reduce anti-social behaviour," Thesis, Durham University, 2010.

[34] Daniel K. Lapsley \& D. Narvaez, Character Education: Handbook of Child Psychology, In Handbook of child psychology, New York: Wiley, 2007.

[35] T. P. Pesantren, Guidelines for the Organization of Modern Muhammadiyah Boarding School Islamic Boarding Schools (In Indonesia: Pedoman Penyelenggaraan Pondok Pesantren Modern Muhammadiyah Boarding School). Yogyakarta: MBS Pleret.

[36] T. Krettenauer, T. Colasante, M. Buchmann, and T. Malti, "The development of moral emotions and decision-making from adolescence to early adulthood: a 6-year longitudinal study," J. Youth Adolesc., vol. 43, no. 4, pp. 583-596, Apr. 2014, doi: 10.1007/s10964-013-9994-5.

[37] K. C. Tsai, "Bring character education into classroom," Eur. J. Educ. Res., vol. 1, no. 2, pp. 163-170, Apr. 2012, doi: 10.12973/eu-jer.1.2.163

[38] M. Davidson, T. Lickona, and V. Khmelkov, "Smart \& good schools a new paradigm for high school character education," Handb. Moral Character Educ., pp. 290-307, 2014, doi: 10.4324/9780203114896.

[39] X. Zhang, W. Admiraal, and N. Saab, "Teachers' motivation to participate in continuous professional development: relationship with factors at the personal and school level," Journal of Education for Teaching, pp. 1-18, 2021, doi: $10.1080 / 02607476.2021 .1942804$

[40] F. R. Ghazalah, "The effect reading Al-Quran on mental health,” Psikoeduko J. Psikol. Edukasi dan Konseling, vol. 1, no. 1, pp. 48-53, 2021.

[41] H. Parkhouse, C. Y. Lu, and V. R. Massaro, "Multicultural education professional development: A Review of the Literature," Rev. Educ. Res., vol. XX, no. X, pp. 1-43, 2019, doi: 10.3102/0034654319840359.

[42] M. White, Robert, "On the reasons we want teachers of good disposition and moral character," J. Teach. Educ., vol. 59, no. 4, pp. 288-299, Sep. 2008, doi: 10.1177/0022487108321377.

[43] A. J. Milson and L. M. Mehlig, "Elementary school teachers' sense of efficacy for character education," J. Educ. Res., vol. 96, no. 1, pp. 47-53, Sep. 2002, doi: 10.1080/00220670209598790.

[44] W. B. Russell and S. Waters, "Developing character in middle school students: a cinematic approach," Clear. House A J. Educ. Strateg. Issues Ideas, vol. 87, no. 4, pp. 161-167, Jul. 2014, doi: 10.1080/00098655.2014.888046. 


\section{BIOGRAPHIES OF AUTHORS}
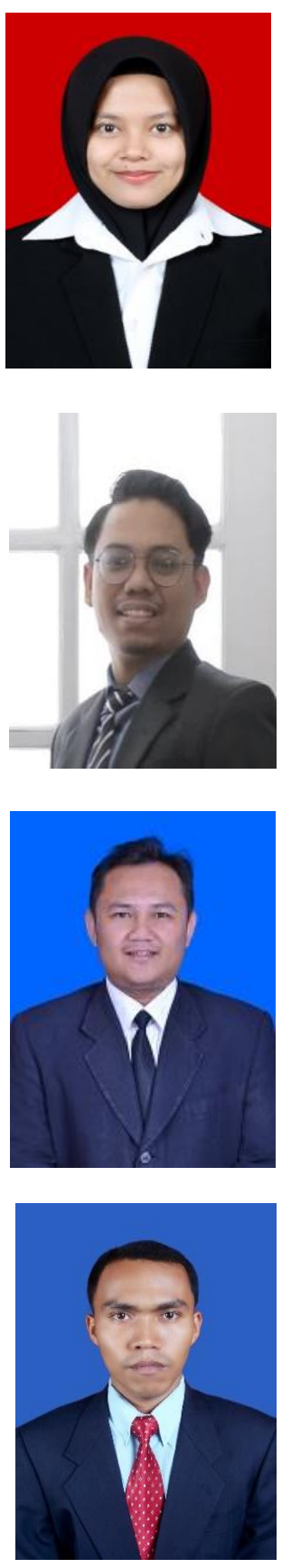

Rahmah Hidayati (D) IS SC P born in Juai May 24, 1997. Graduated from the Department of Islamic Education, Universitas Ahmad Dahlan, Indonesia. Currently a teacher of Islamic Education at Junior High School 5 Halong, South Kalimantan. The research conducted is related to Character Education, Development of learning materials, and teaching methods. She can be contacted at email: rahmahhidayati91@ gmail.com.

Arif Rahman (D) FI SC P is a lecturer and researcher, is the Deputy Dean of the Faculty of Islamic Studies at Ahmad Dahlan University. Previously he was a teacher at Senior High School of Muhammadiyah 1 in Yogyakarta. Arif Rahman received a Bachelor's degree in Islamic Education from State Islamic University of Raden Fatah and a Master's degree in Islamic Education from State Islamic University of Sunan Kalijaga, currently completing his doctoral in Islamic Studies at the same campus before. His research focuses on social studies, history, and critical pedagogy. For the past few years he has also been involved in collaborative research on the impact of COVID-19 on the halal fashion industry in Indonesia. He can be contacted at email: arif.rahman@ pai.uad.ac.id.

Zalik Nuryana (D) 8. SC P is an assistant professor at Universitas Ahmad Dahlan Indonesia, Islamic Education department. He is currently a Ph.D. student in School of Education Science, Nanjing Normal University China. His areas of interest include curriculum development, teaching method, and online learning. Zalik Nuryana can be contacted at zalik.nuryana@pai.uad.ac.id; zalik@ascee.org; zalik@ieee.org.

Yusutria (iD SC P is is an Born in Padang, December 20, 1982. The fifth child of six children from the couple Bahar and Arni. His education level is Elementary School at SD Negeri 05 Surau Gadang, Nanggalo Padang Regency, West Sumatra, then continued to Pondok Modern Babussalam (PMB) Kerjo Kebonsari Madiun East Java and Pondok Modern Darussalam Gontor (PMDG) Ponorogo East Java. In 2002, he continued his undergraduate education in the field of Islamic Religious Education at the Department of Islamic Education, Faculty of Tarbiyah IAIN Imam Bonjol Padang, until he finished in 2006. Then in 2007, he continued his master's education in the Department of Islamic Religion. Education at the Postgraduate Program of IAIN Imam Bonjol Padang and completed in 2007 2009. In 2011 he continued his doctoral education at the Department of Islamic Education and completed it in 2016. Currently a permanent lecturer at Ahmad Dahlan University (UAD) Yogyakarta, at the Faculty of Islamic Religion (FAI). He can be contacted at email: yusutria@ pai.uad.ac.id. 